\title{
Effect of Previous Crop Load on Stigmatic Morphology of Apple Flowers
}

\author{
Deborah Buszard \\ Department of Plant Science, Faculty of Agricultural and Environmental Sciences, McGill University, \\ 21111 Lakeshore Road, Sainte Anne-de-Bellevue, PQ, Canada H9X $3 V 9$
}

\author{
W.W. Schwabe \\ Department of Horticulture, Wye College, University of London, England
}

Additional index words. Pyrus domestics

\begin{abstract}
Cox's Orange Pippin' apple (Pyrus domestics Berth.) trees, which were previously heavily cropped compared to previously defruited trees, had smaller flowers, lower initial fruit set, and a shorter effective pollination period (EPP) than defruited trees. The morphology of apple flower styles and stigmas was studied using scanning and transmission electron microscopy. Virgin stigmas from previously unstressed trees had fully expanded papillae, but 7 days after pollination the papillae were collapsed and distinct pollen tubes penetrated the stigmatic surface. Virgin stigmas from flowers of previously heavily cropped trees were smaller than those from previously defruited trees. The virgin stigmas of the flowers of heavily cropped trees showed collapsed papillae, and differences were observed in the intercellular material in the subtending transmitting tissue. These differences may explain the poor fruit setting characteristics of apple flowers on trees that have borne a heavy crop in the previous year.
\end{abstract}

Cultivars with a biennial bearing habit produce few flower buds in cropping years (Luckwill, 1970), and the number of flower buds is decreased as crop load increases (Abbott, 1984). Williams et al. (1980) showed that the earlier fruit were picked in a cropping year, the better the yield in the subsequent year. This was initially attributed to insufficient nutrients remaining for bud development after fruit demands had been satisfied (Childers, 1978), but later defoliation experiments showed inhibition of bud development to be hormonal rather than nutritional (Fulford, 1966a). Chan and Cain (1967) found that parthenocarpic fruit did not inhibit bud development, whereas seeded fruit did, and concluded that the effect of fruit on return bloom was caused by the seeds and was an hormonally regulated process. The main effect of the presence of developing fruit in a cropping year is to lengthen the plastochron, potentially to such an extent that floral primordia fail to develop (Abbott, 1977). The plastochron in developing buds is normally 7 days during the 4 weeks after full bloom, regardless of fruit load; however, after this period, cell division in the cortex of fruitlets is reduced (Denne, 1960), coinciding with a peak in seed-gibberellin production (Luckwill et al., 1969).

Flower quality, that is, the ability of a flower to develop into a fruitlet after pollination with compatible pollen during the flower's receptive period, is linked to ovule maturity and longevity and pollen receptivity at the stigmatic surface. Jackson et al (1981), studying poor fruit set in flowers exposed to high preblossom temperatures, found that misting treatments to cool blossoms delayed flowering, but that at anthesis a greater proportion of ovules were mature in the cooled vs. control flowers. With respect to previous cropping, Williams (1970) showed that the effective pollination period (EPP) was shorter in the off-year than in the cropping year. Schwabe (1978) showed that a large crop load in one season resulted in smaller flower buds in the subsequent offyear. The study presented here sought to determine the-effect of prior fruit load on morphology and function of apple flowers, particularly with respect to stigmatic anatomy.

Received for publication 19 Aug. 1994, Accepted for publication 7 Feb. 1995. We thank G.T. Dodds, Dept. of Agricultural Engineering, McGill Univ., for preparing this manuscript. The cost of publishing this paper was defrayed in part by the payment of page charges. Under postal regulations, this paper therefore must be hereby marked advertisement solely to indicate this fact.

\section{Materials and Methods}

All experiments were carried out on 'Cox's Orange Pippin' on

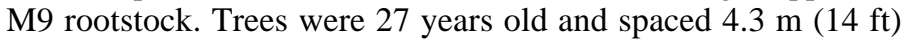
apart. The orchard received the standard apple pest and disease management program. At petal fall in year 1 of this study, 11 trees each were either completely defruited or allowed to carry a heavy fruit load. Flowers were collected in the following spring from five trees that had been selected in the previous year for uniformity of flowering density.

Macroscopic observations. Five spur clusters per tree per treatment were observed at anthesis in year 2, and leaf number and area, flower number, pedicel and peduncle lengths, and receptacle diameter were measured. Five trees in each group of eleven were selected such that their average trunk cross-sectional areas did not differ significantly. On each tree a branch unit, comprising at least 25 flower clusters, was hand pollinated with compatible viable pollen ('Millers' Seedling') as the flowers opened to estimate female fertility. Fruit set was determined initially (30 days postanthesis) and at harvest (120 days postanthesis). Total number of fruit per tree was also determined.

Lastly, 50 clusters in both axillary ( 1-year-old wood) and spur (2- or 3-year-old wood) positions were selected on both tree types for synchronous anthesis to determine the effective pollination period (Williams, 1970). Because of later flower development on the heavily cropped trees, pollination of these trees began 3 days later than on the defruited trees. All clusters were thinned to the four most similar flowers, removing the king flower and any other extra flowers. Each flower was emasculated and depetalled at the late pink balloon stage to prevent self-or cross-pollination. Each day for the next 10 days following depetalling, five clusters of four flowers of each type were randomly selected and pollinated using compatible, viable pollen. Fruit set after 30 days was taken as being representative of EPP.

Data analysis. Treatments were compared by simple t tests (Daniel, 1978). Percentages were analyzed using an arcsin transformation.

Preparation for transmission electron microscopy. For transmission and scanning electron microscopy, flowers were collected at anthesis and the styles were immediately severed at the base and 
placed in cold (4C) $0.1 \mathrm{M}$ cacodylate-buffered $2.6 \%$ glutaraldehyde, $\mathrm{pH}$ 7.0-7.3 (fixative solution). Tissue was cut into sections about $5 \mathrm{~mm}$ long, the stigma and top-portion of the style and the mid-portion of the style. To allow later orientation of the midportion, the basal cut was made diagonally. Four tissue pieces were placed in vials containing $5 \mathrm{ml}$ of fixative solution and held at $4 \mathrm{C}$ for $24 \mathrm{~h}$. Tissue was then washed repeatedly in cold $0.1 \mathrm{M}$ cacodylate buffer to remove all free glutaraldehyde. Tissue was then placed in $4 \mathrm{ml}$ of cacodylate buffered $0.1 \mathrm{M}$ osmium tetroxide at $20 \mathrm{C}$ for $1 \mathrm{~h}$. This was followed by ethanol dehydration of the tissue according to Glauert ( 1975). The resin used for embedding was an Epon-araldite mixture consisting of $24 \mathrm{~g}$ araldite CY212, $30 \mathrm{~g}$ Epon 812,72 g DDSA (HY964), and $2.6 \mathrm{~g}$ DMP-30 (DY 064) (Anderson and Andre, 1968). To aid penetration of the resin, 1,2epoxy propane was used as a link reagent. After removal of the absolute ethanol, a 1:1 (v/v) mixture of ethanol and 1,2-epoxy propane was added, and the tissue left in it for $16 \mathrm{~min}$. Half of the mixture was removed and replaced with 1,2-epoxy propane. After 16 tin, the entire mixture was replaced with 1,2-epoxy propane. After 30 rein, the 1,2-epoxy propane was replaced by a 1:1 mixture of 1,2-epoxy propane and resin, and this was left overnight in an uncovered vial to allow evaporation of the 1,2-epoxy propane. Tissue pieces were then transferred to vials containing sufficient fresh resin to cover them. This was repeated twice, at 2-h intervals. Tissue was then transferred to embedding molds. After $1 \mathrm{~h}$, molds were placed in a $60 \mathrm{C}$ oven for $48 \mathrm{~h}$ to polymerize the resin. Sections were cut using an LKB Ultratome III. Knives used were prepared using an LKB knife maker using strips of float glass (Taab Laboratories, Reading, England). Sections varying in thickness between 60 and $100 \mathrm{~nm}$ were obtained and collected on 300 mesh copper grids. Sections were stained with uranyl acetate-lead citrate (Lewis and Knight, 1977). Sections were examined using an AEI Corinth transmission electron microscope, and photographs made using Ilfolith Contact IC 4 film (Ilford Ltd., London, England).

Preparation for scanning electron microscopy. Whole pistils were removed from flowers at stages from pink balloon to petal fall and fixed as for transmission electron microscopy. Tissue was dehydrated in acetone-water (v/v) as follows: $50 \%(15 \mathrm{~min}), 70 \%$ (15 min), 80\% (15 min), 90\% (15 min), 100\% (15 min), 100\% (30 rein) series. Tissue was critical-point-dried using liquid $\mathrm{CO}_{2}$ (Hayat, 1978). Specimens were mounted on stubs and gold coated using a Balzers Union sputter coater before examination using the Jeol JSM 35 electron microscope. Photographs were obtained as for transmission electron microscopy.

\section{Results}

While leaf number and area and flower number on spur clusters were not significantly affected by prior crop load, pedicel length, peduncle length, and receptacle diameter were all smaller on the previously heavily cropped trees (Table 1 ). The number of flower clusters per tree was 2.5 -fold greater and the final yield (fruits per tree) was nearly double on the defruited trees compared to those previously heavily cropped (Table 2). Initial percentage fruit set on defruited trees was about 3.5 times that on heavily cropped trees, but final percent fruit set was about $30 \%$ greater on previously heavily cropped trees (Table 2). This was probably related to increased fruit drop on defruited trees, where competition between developing fruit was much greater than on the previously heavily cropped trees.

Previous crop load also influenced the EPP (Table 3). Flowers on defruited trees were receptive to pollen at anthesis, but flowers on previously heavily cropped trees were not receptive until day 3 . Previously heavily cropped trees achieved maximum fruit set when pollinated at day 3 with essentially no fruit set after day 7 , whereas defruited trees set fruit when pollinated through day 10 . The EPP was 10 days for flowers from defruited trees and barely 6 days for the previously heavily cropped trees.

The stigma and style of a typical 'Cox's Orange Pippin' flower at anthesis, before pollination, prepared by critical-point drying and gold coating are shown in Fig. 1A. The style has been fractured longitudinally to show the inner structures (Fig. 1B). The papillae of the stigmatic surface can be seen clearly, but following the

Table 1. Effect of previous season's crop load on leaf number and area, flower number, pedicel and peduncle lengths, and receptacle diameter in the subsequent year.

\begin{tabular}{|c|c|c|}
\hline Parameter $^{2}$ & $\begin{array}{c}\text { Defruited } \\
\text { trees }\end{array}$ & $\begin{array}{c}\text { Heavily } \\
\text { cropped } \\
\text { trees }\end{array}$ \\
\hline Leaf no. & 7.6 & $7.2^{\mathrm{Ns}}$ \\
\hline Total leaf area $\left(\mathrm{mm}^{2}\right)$ & 10190 & $6560^{\text {NS }}$ \\
\hline Flower number & 4.8 & $4.4^{\mathrm{NS}}$ \\
\hline Pedicel length (mm) & 11.6 & $8.4^{*}$ \\
\hline Peduncle length (mm) & 12.4 & $7.0^{*}$ \\
\hline Receptacle diameter (mm) & 3.3 & $2.7^{*}$ \\
\hline
\end{tabular}

${ }^{2}$ Values are means of five clusters.

${ }^{\text {ss }}$, Nonsignificant or significant at $P \leq 0.05$ or $>0.05$, respectively, by Student's $t$ test.

Table 2. Effect of previous crop load on number of flower clusters, initial and final fruit set percentage, and total number of fruit per tree.

\begin{tabular}{|c|c|c|}
\hline Parameter $^{2}$ & $\begin{array}{c}\text { Defruited } \\
\text { trees }\end{array}$ & $\begin{array}{c}\text { Heavily } \\
\text { cropped } \\
\text { trees }\end{array}$ \\
\hline$\overline{\text { Flower cluster no./tree }}$ & 756 & $288^{*}$ \\
\hline Initial fruit set (30 days) (\%) & 33.8 & $9.2^{*}$ \\
\hline Final fruit set (120 days) (\%) & 6.0 & $7.8^{*}$ \\
\hline Fruit no./tree & 213 & $111^{*}$ \\
\hline
\end{tabular}

${ }^{\overline{2}}$ Values are means of five trees.

${ }^{\text {Ns }}$, Nonsignificant or significant at $P £ 0.05$ or $>0.05$, respectively, by Student's $t$ test.

Table 3. Effects of previous crop load on the effective pollination period of flowers developed from spur or axillary clusters-and fruit set.

\begin{tabular}{|c|c|c|c|c|}
\hline \multirow[b]{3}{*}{$\begin{array}{l}\text { Day of } \\
\text { pollination }\end{array}$} & \multicolumn{4}{|c|}{ Initial fruit set $(\%)^{c}$} \\
\hline & \multicolumn{2}{|c|}{ Defruited trees } & \multicolumn{2}{|c|}{ Heavily cropped trees } \\
\hline & $\begin{array}{c}\text { Spur } \\
\text { clusters }\end{array}$ & $\begin{array}{l}\text { Axillary } \\
\text { clusters }\end{array}$ & $\begin{array}{c}\text { Spur } \\
\text { clusters }\end{array}$ & $\begin{array}{l}\text { Axillary } \\
\text { clusters }\end{array}$ \\
\hline Anthesis & 45 & 30 & 0 & 0 \\
\hline 2 & 5 & 30 & 5 & 5 \\
\hline 3 & 25 & 40 & 15 & 45 \\
\hline 4 & 30 & 25 & 5 & 10 \\
\hline 5 & 10 & 50 & 10 & 5 \\
\hline 6 & 20 & 25 & 15 & 0 \\
\hline 7 & 20 & 10 & 15 & 10 \\
\hline 8 & 0 & 5 & 0 & 0 \\
\hline 9 & 20 & 5 & 0 & 0 \\
\hline 10 & 5 & 15 & 0 & 5 \\
\hline
\end{tabular}

${ }^{2}$ Initial fruit set $=$ fruit retained after 30 days. 


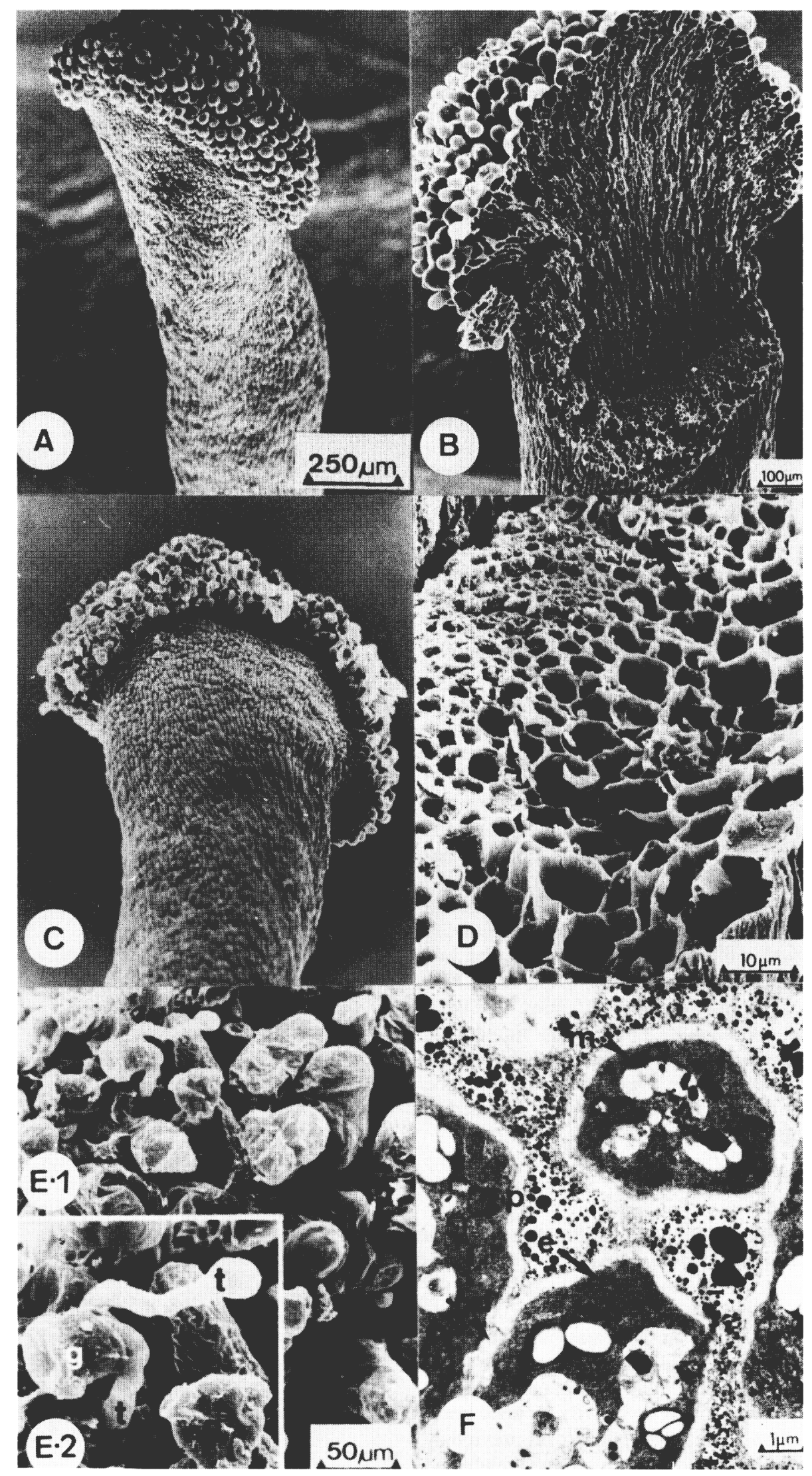

Fig. 1.Scanning and transmission electron micrographs of the stigma and style of 'Cox's Orange Pippin' apple flowers: (A) at anthesis, unpollinated (tissue critical-point dried, gold coated); (B) longitudinal fracture (critical point dried, not gold coated); (C) flower 7 days after pollination at anthesis (critical-point dried, gold coated); (D) base of the longitudinal fracture magnified, arrow shows xylem vessels; (E) collapsed papillae and shrivelled and broken pellicle (E-1). Germinated pollen grains $(\mathrm{g})$ and tubes $(\mathrm{t})$ penetrating the stigmatic surface (E-2); F) transmission electron micrograph of a stylar cross-section about $2 \mathrm{~mm}$ below the stigmatic surface. (e) endoplasmic reticulum, (m) mitochondria, (p) plastid, and (pm) plasmadesmata. 


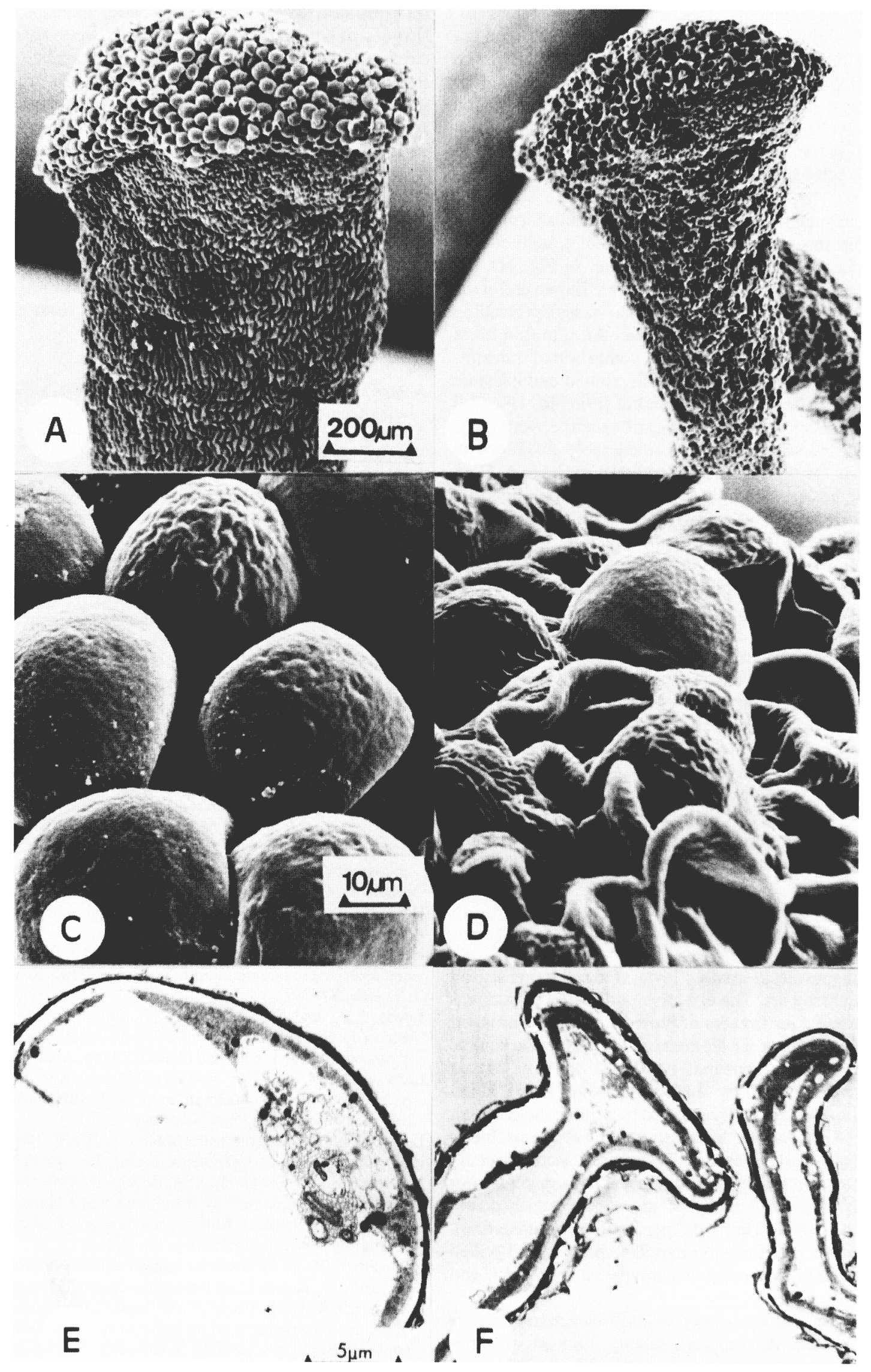

Fig. 2. Scanning and transmission electron micrographs of the stigma and style of 'Cox's Orange Pippin' apple flowers: previously defruited tree (A) and previously heavily cropped tree (B), at anthesis; papillae from flowers on a previously defruited tree (C) and a previously heavily cropped tree (D); ultrathin sections of papillae from the stigma of a flower on a previously defruited tree $(\mathbf{E})$ and heavily cropped tree. 
critical point drying treatment, none of the liquid exudate remained. Figure $1 \mathrm{C}$ and $\mathrm{E}$ shows the effects of pollination on the apple stigma. In Fig. 1A, the stigma is seen at anthesis, before pollination. The papillae can be seen to be fully expanded. In Fig. $1 \mathrm{C}$, the stigma is seen 7 days after pollination at anthesis. The papillae have shrivelled and the pellicle is broken and torn. Many pollen grains are present, and pollen tubes can be seen penetrating between papillae in the magnification of Fig. $1 \mathrm{C}$ seen in Fig. $1 \mathrm{E}$ 1 and $1 \mathrm{E}-2$.

The style has an outer layer of parenchymatous cells forming an epidermis. Within this the tissue is made up of longitudinally elongated cells forming the transmitting tissue. In Fig. $1 \mathrm{D}$, the arrangement of cells in the transmitting tissue are shown and at the top of the picture (arrow) spiral thickening can be seen protruding from the fractured remains of xylem tissue. An ultrathin cross section, $2 \mathrm{~mm}$ below the stigmatic surface, comprised of transmitting tissue, shows sparsely vacuolated cells, rich in endoplasmic reticulum (e), plastids (p), and mitochondria (m) (Fig. IF). Cell walls are thick and plasmodesmata $(\mathrm{pm})$ can be seen between cells. Between cells the middle lamella is considerably thickened to provide the matrix through which pollen tubes may grow. Dark staining areas are unsaturated lipids which are osmiophilic.

Flower: collected from previously bearing and nonbearing trees showed distinct differences in appearance of stigmas and styles. Pistils of flowers from previously defruited trees (Fig. 2A) were larger than those from previously heavily cropped trees (Fig. 2B). Most of the papillae of stigmas from defruited trees were fully expanded at anthesis (Fig. 2C), while those from previously heavily bearing trees were unexpanded (Fig, 2D). Ultrathin sections of papillae confirmed the scanning electron microscope results, showing significant differences between the flowers from the two tree groups. In a cross-section through a fully expanded papilla, the remains of the pellicle and exudate can be seen (Fig. $2 \mathrm{E}$ ). The cell comprises a massive vacuole and the dense cytoplasm is pressed against the cell wall. A cross section through a collapsed papilla from a previously heavily bearing tree (Fig. 2F) reveals a distinctly different papillar shape, but pellicle, exudate and cell contents are similar to those in an expanded papillae (Fig. 2E).

\section{Discussion}

Heavy cropping results in smaller flowers the following season and reduced initial fruit set. The effective pollination period was delayed and shortened for flowers of previously heavily cropped trees which likely accounts for the reduced fruit set observed.

The stigmatic surface appeared typical of the wet stigma described for the Pomoideae by Heslop-Harrison (1975). However, Malus papillae are generally covered by a thin cuticle, which is lifted away between papillae by the stigmatic secretions, forming a loose covering, which is eventually ruptured (Hattingh et al., 1986; Heslop-Harrison, 1975). This cuticle was not apparent in our observations, but some apple cultivars' stigmas apparently do not have this structure (M.J. Hattingh, personal communication). Once pollination has occurred, the papillae collapse and pollen tubes penetrate the pellicle and grow down the style (Fig. $1 \mathrm{C}$ and E).

There were striking differences between flower characteristics and fruit set associated with cropping history. Flowers of previously defruited trees were most receptive to pollen at anthesis, as evidenced by their good fruit set. In contrast, fruit set of flowers on previously heavily cropped trees was poor at anthesis, with their best response to pollination 3 days after anthesis. The stigmata of flowers initiated on nonbearing trees were covered with fully expanded papillae at anthesis and were carried on a thick style. Papillae from flowers from previously heavily cropped trees were unexpanded at anthesis and styles were thinner. Differences in stylar size were paralleled by those of other flower parts (Table 1).

It may be that papillae must be fully expanded to allow the hydration and germination of pollen grains deposited on the stigma, and that the expansion of papillae from flowers of previously heavily cropped trees is delayed sufficiently to result in a substantial reduction in the initial fruit set and EPP.

The results of this study provide evidence that floral morphology plays a key role in the EPP and initial fruit set of apple and that morphology is itself influenced by the previous cropping load.

\section{Literature Cited}

Abbott, D.L. 1977. Fruit-bud formation in Cox's Orange Pippin. Report Long Ashton Res. Sta. for 1976. p. 167-176.

Abbott, D.L. 1984. The apple tree. Physiology and management. Grower Books, London

Anderson, W.A. and J. André. 1968. The extraction of some cell components with pronase and pepsin from thin sections of tissue embedded in an Epon-Araldite mixture. J. Microscopy 7:343-354.

Chan, B.G. and J.C. Cain. 1967. The effect of seed formation on subsequent flowering in apple. Proc. Amer. Soc. Hort. Sci. 91:63-68.

Childers, N.F. 1978. Modem fruit science: Orchard and small fruit culture. 8th ed. Horticulture Publishers, Rutgers Univ., New Brunswick, N.J.

Daniel, W.W. 1978. Biostatistics: A foundation for analysis in the health sciences. 2nd ed. Wiley, New York.

Denne, M.P. 1960. The growth of apple fruitlets and the effect of early thinning on fruit development. Ann. Bet. 24:397-406.

Fulford, R.M. 1966a. The morphogenesis of apple buds. III. The inception of flowers. Ann. Bet. 30:207-219.

Fulford, R.M. 1966b. The morphogenesis of apple buds. IV. The effect of fruit. Ann. Bet. 30:597-606.

Glauert, A.M. 1975. Fixation dehydration and embedding of biological specimens. In: A.M. Glauert (ed.). Practical methods in electron microscopy. vol. 3. part 1. North Holland, Amsterdam.

Hattingh, M. J., S.V. Beer, and E.W. Lawson. 1986. Scanning electron microscopy of apple blossoms colonized by Erwinia amylovora and $E$. herbicola. Phytopathology 76:900-904.

Hayat, M.A. 1978. Introduction to biological scanning electron microscopy. University Park Press, Baltimore.

Heslop-Harrison, J., Y. Heslop-Harrison, and J. Barber. 1975. The stigmatic surface in incompatibility responses. Proc. Royal Soc. (London) (B) 188:287-297.

Lewis, P. R., and D.P. Knight. 1977. Staining methods for sectioned materials. In: A.M. Glauert (ed.). Practical methods in electron microscopy. vol. 5. part 1. Elsevier-North Holland, Amsterdam.

Luckwill, L.C. 1970. The control of growth and fruitfulness of apple trees, p. 237-254. In: L.C. Luckwill and C.V. Cutting (eds.). Physiology of tree crops. Academic Press, London.

Luckwill, L. C., P. Weaver, and J. Macmillan. 1969. Gibberellins and other growth hormones in apple seeds. J. Hort. Sci. 44:413-424.

Jackson, J. E., P.J.C. Hamer, S.M. El Senfaz, M.M. Fuller, D.S. Skene, M.F. Wickenden, C. Ball, M. Brookfield, and P. Newman. 1981. Control of flower development, fruit set, fruit size and fruit quality. Annu. Rpt. E. Mailing Res. Sta. for 1980. p. 26-29.

Schwabe, W .W. 1978. Growth regulators and the control of development in fruit trees. British Crop Protection Council Monogr. 21: 143-157.

Williams, R. R., G.M. Arnold, V.A. Flook, C.J. Jefferies. 1980. The effect of picking date on blossoming and fruit set in the following year for the apple cv. Bramley's seedling. J. Hort. Sci. 55:359-362.

Williams, R.R. 1970. Factors affecting pollination in fruit trees, p. 193205. In: L.C. Luckwill and C.V. Cutting (eds.). Physiology of tree crops. Academic Press, London. 